\title{
Standardized Postoperative Recovery Reduces in-Hospital Stay After Minimally Invasive Esophagectomy
}

\author{
Anna Katrine Nyman Rasmussen, Michael Hareskov Larsen, Alan Patrick Ainsworth* \\ Department of Surgery, Odense University Hospital, Odense C, Denmark
}

Email address:

alan.ainsworth@dadlnet.dk (A. P. Ainsworth)

${ }^{*}$ Corresponding author

\section{To cite this article:}

Anna Katrine Nyman Rasmussen, Michael Hareskov Larsen, Alan Patrick Ainsworth. Standardized Postoperative Recovery Reduces inHospital Stay After Minimally Invasive Esophagectomy. Journal of Surgery. Vol. 9, No. 2, 2021, pp. 53-57. doi: 10.11648/j.js.20210902.12

Received: February 20, 2021; Accepted: March 4, 2021; Published: March 12, 2021

\begin{abstract}
Background: This study aims to examine if a standardized enhanced recovery program (ERP) could reduce the length of stay (LOS) after minimally invasive esophagectomy (MIO) compared to the earlier applied recovery program without increasing the risk of postoperative complications and readmissions. Methods: Retrospective study of patients with esophageal and gastroesophageal junction cancer who have had an uncomplicated postoperative stay following MIO. Patients had followed two different postoperative recovery programs according to their year of surgery (2016 versus 2018). Results: 48 patients in 2016 and 42 patients in 2018 were included. Patients were comparable on demographic factors. The median LOS was reduced from 9 days in 2016 to 8 days in 2018 ( $<<0.001$ ). In 2018, 27 patients $(64.3 \%$ ) fulfilled the aim of discharge to their own home on day 8 after surgery. There was no significant difference $(p>0.05)$ between the two groups in the risk of complications (Clavien-Dindo degree 0-2). Two patients in $2016(4.2 \%)$ and two patients in 2018 (4.8\%) were readmitted within 7 days after discharge (not significant). There was no in-hospital mortality or 30-day mortality in either of the two groups. Conclusion: The introduction of an ERP at our institution reduced the median postoperative stay after MIO by one day without increasing the risk of complications and readmittance. Further reduction might be obtained if oral feeding is allowed earlier.
\end{abstract}

Keywords: Enhanced Postsurgical Recovery Esophagectomy, Neoplasms, Operative Surgical Procedure, Laparoscopy, Thoracoscopy

\section{Introduction}

Curative treatment of cancer in the esophagus or at the gastroesophageal junction (GEJ) consists of surgery often combined with perioperative oncological treatment. Previously, surgery was extensive including both a laparotomy and a thoracotomy but recently minimally invasive esophagectomy (MIO) had gained increasing popularity. Thus, large incisions are avoided by MIO and, in addition, the technique has been associated with reduced risk of cardio-pulmonary complications, less intraoperative blood loss and shorter length of stay (LOS) [1].

Since 2016, MIO has been the standard technique for the surgery for esophageal or GEJ cancer at our institution. Details on the procedure have been described earlier [2]. At first the department's postoperative recovery program was the same as the one in the open era, but after getting familiar with the new surgical technique we started to apply a standardized postoperative enhanced recovery program (ERP) on the patients. ERP is based on a multidisciplinary approach to recovery after surgery and it requires a broad professional collaboration between surgeons, nurses, dieticians, anesthesiologists, and physiotherapists. ERP aims to reduce the stress response after surgery and by doing so improve short-term outcomes associated with surgical procedures along with the quality of recovery [3,4]. The concept of ERP was first introduced in colorectal surgery [5], but has later also been applied in other surgical fields. Thus, guidelines on ERP after colorectal surgery, liver surgery and gastrectomy have existed for some years [6-8], and guidelines on ERP following esophagectomy have recently been published but these are primarily based on experience from the open era [9]. 
This study aims to examine if a standardized ERP could reduce the LOS after MIO compared to the earlier applied recovery program without increasing the risk of postoperative complications and readmissions.

\section{Patients and Methods}

This study consists of all patients who had undergone MIO with an uncomplicated postoperative stay in 2016 and in 2018 at The Department of Surgery, Odense University Hospital. Patients were identified from a quality database (approval by the Region of Southern Denmark (registration number 18/37355)). The patients' case records were searched for additional data. Patient characteristics included: gender, age, body mass index (BMI), preoperative histology, American Society of Anesthesiologists (ASA) classification, clinical stage of tumor and regional lymph nodes (cTNM), neoadjuvant treatment, LOS, complications (according to the
Clavien-Dindo classification [10]), readmissions and mortality (in-hospital and 30-day). Patients were divided into two groups depending on their year of surgery: 2016 or 2018. The difference between recovery in 2016 and the standardized ERP of 2018 was earlier mobilization and earlier oral food intake along with an earlier removal of drains and tubes. Thus, in the 2018 program epidural catheter and bladder catheter was removed at day 4 after surgery, whereas semi-solid food was allowed day 5 and normal food at day 7. Discharge from hospital to the patient's own home was aimed at day 8 (Figure 1). Both in 2016 and in 2018 patients could be discharged any day of the week including weekends and rounds were done 7days a week in both years by the same team of consultants with special qualification in upper gastrointestinal surgery. However, in 2018 all patients were handed out their plan for recovery in layman language and the standardized plan for postoperative care hung on a poster at the ward (Figure 1) and was easily visible to all attending nurses.

\begin{tabular}{|c|c|c|c|c|c|c|c|c|c|c|}
\hline & Day 0-ICU & Day 1 & Day 2 & Day 3 & Day 4 & Day 5 & Day 6 & Day 7 & Day 8 & Day 9 \\
\hline \multicolumn{11}{|l|}{ Nutrition } \\
\hline Peros & Clear fluid & Clear fluid & Clear fluid & Clear fluid & Clear fluid & Semi solid & Semi solid & Solid food & Solid food & Solid food \\
\hline Enteral & $\begin{array}{c}10 \mathrm{ml} / \mathrm{h} \text { Nutrison } \\
\mathrm{energy}^{\circ}\end{array}$ & $\begin{array}{c}25 \mathrm{ml} / \mathrm{h} \text { Nutrison } \\
\text { energy }\end{array}$ & $\begin{array}{c}25 \mathrm{ml} / \mathrm{h} \text { Nutrison } \\
\text { energy }^{\circ}\end{array}$ & $\begin{array}{c}50 \mathrm{ml} / \mathrm{h} \text { Nutrison } \\
\text { energy }\end{array}$ & $\begin{array}{c}50 \mathrm{ml} / \mathrm{h} \text { Nutrison } \\
\text { energy }\end{array}$ & $\begin{array}{l}75 \mathrm{ml} / \mathrm{h} \text { Nutrison } \\
\text { energy }^{\circ}\end{array}$ & $\begin{array}{c}\text { Full enteral - if } \\
\text { flatus/defaecation }\end{array}$ & $\begin{array}{c}\text { Full enteral - if } \\
\text { flatus/defaecation }\end{array}$ & \begin{tabular}{|c|}
$\begin{array}{c}\text { Full enteral - if } \\
\text { flatus/defaecation }\end{array}$ \\
\end{tabular} & \begin{tabular}{|c|} 
Full enteral - if \\
flatus/defaecation
\end{tabular} \\
\hline Blood glucose & $\begin{array}{c}\begin{array}{c}\text { BG } \times 8+\text { insuman } \\
\text { on demand }\end{array} \\
\end{array}$ & $B G \times 4$ & $B G \times 4$ & $\begin{array}{c}\text { Evaluation, possibly } \\
\text { discontinuation }\end{array}$ & $\begin{array}{c}\text { Evaluation, possibly } \\
\text { discontinuation }\end{array}$ & $\%$ & $\%$ & $\%$ & $\%$ & $\%$ \\
\hline \begin{tabular}{|l|} 
Dietitian \\
\end{tabular} & $\%$ & $\%$ & $\%$ & $\%$ & Scheduled & Optional & Optional & Optional & Optional & Optional \\
\hline $\begin{array}{l}\text { Fluid balance } \\
\text { chart }\end{array}$ & ICU & $\begin{array}{c}\text { Expanded fluid } \\
\text { balance }\end{array}$ & $\begin{array}{c}\text { Expanded fluid } \\
\text { balance + weight } \\
\text { measurement }\end{array}$ & $\begin{array}{c}\text { Expanded fluid } \\
\text { balance + weight } \\
\text { measurement }\end{array}$ & $\begin{array}{c}\begin{array}{c}\text { Fluid balance + } \\
\text { weight measurement }\end{array} \\
\end{array}$ & \begin{tabular}{|c|}
$\begin{array}{c}\text { Fluid balance + } \\
\text { weight measurement }\end{array}$ \\
\end{tabular} & \begin{tabular}{|c|}
$\begin{array}{c}\text { Fluid balance + } \\
\text { weight measurement }\end{array}$ \\
\end{tabular} & \begin{tabular}{|c|}
$\begin{array}{c}\text { Fluid balance + } \\
\text { weight measurement }\end{array}$ \\
\end{tabular} & $\begin{array}{c}\text { Fluid balance + } \\
\text { weight } \\
\text { measurement }\end{array}$ & $\%$ \\
\hline \multicolumn{11}{|l|}{ Excretion } \\
\hline $\boldsymbol{P}$-chest tube & & $\begin{array}{c}<250 \mathrm{ml} \text { - possibly } \\
\text { removal after } \\
\text { evaluation }\end{array}$ & $\begin{array}{c}<250 \mathrm{ml} \text { - possibly } \\
\text { removal after } \\
\text { evaluation }\end{array}$ & $\begin{array}{c}<250 \mathrm{ml} \text { - possibly } \\
\text { removal after } \\
\text { evaluation }\end{array}$ & $\begin{array}{c}<250 \mathrm{ml} \text { - possibly } \\
\text { removal after } \\
\text { evaluation }\end{array}$ & $\begin{array}{c}<250 \mathrm{ml} \text { - possibly } \\
\text { removal after } \\
\text { evaluation }\end{array}$ & $\begin{array}{c}<250 \mathrm{ml} \text { - possibly } \\
\text { removal after } \\
\text { evaluation }\end{array}$ & $\begin{array}{c}<250 \mathrm{ml} \text { - possibly } \\
\text { removal after } \\
\text { evaluation }\end{array}$ & \begin{tabular}{|c|}
$\begin{array}{c}<250 \mathrm{ml} \text { - possibly } \\
\text { removal after } \\
\text { evaluation }\end{array}$ \\
\end{tabular} & $\%$ \\
\hline$M$-chest tube & & $\begin{array}{l}\text { Observe amount } \\
\text { and appearance }\end{array}$ & $\begin{array}{c}\text { Observe amount and } \\
\text { appearance }\end{array}$ & $\begin{array}{l}\text { Observe amount } \\
\text { and appearance }\end{array}$ & $\begin{array}{c}\text { Observe amount and } \\
\text { appearance }\end{array}$ & $\begin{array}{c}\text { Observe amount and } \\
\text { appearance }\end{array}$ & $\begin{array}{c}\text { Observe amount and } \\
\text { appearance }\end{array}$ & \begin{tabular}{|c|} 
Remove $\mathrm{M}$-chest \\
tube after evaluation
\end{tabular} & & \\
\hline \begin{tabular}{|l|} 
Bowel \\
function
\end{tabular} & $\%$ & $\%$ & $\%$ & $\%$ & $\begin{array}{l}\text { Enema if no } \\
\text { defeacation }\end{array}$ & $\begin{array}{l}\text { Enema if no } \\
\text { defeacation }\end{array}$ & $\begin{array}{l}+ \text { flatus and } \\
\text { defaecation }\end{array}$ & $\begin{array}{l}+ \text { flatus and } \\
\text { defaecation }\end{array}$ & $\begin{array}{l}\text { flatus and } \\
\text { defaecation }\end{array}$ & $\begin{array}{c}\text { +flatus and } \\
\text { defaecation }\end{array}$ \\
\hline NG tube & $\mathrm{x}$ & Total aspirate & Total aspirate & Total aspirate & $\begin{array}{l}\text { Negative aspirate - } \\
\text { remove }\end{array}$ & $\begin{array}{l}\text { Negative aspirate - } \\
\text { remove }\end{array}$ & $\begin{array}{l}\text { Negative aspirate - } \\
\text { remove }\end{array}$ & $\begin{array}{c}\text { Negative aspirate - } \\
\text { remove }\end{array}$ & $\begin{array}{c}\text { Negative aspirate - } \\
\text { remove }\end{array}$ & $\begin{array}{c}\text { Negative aspirate - } \\
\text { remove }\end{array}$ \\
\hline \begin{tabular}{|l|}
$\begin{array}{l}\text { Urine } \\
\text { catheter }\end{array}$ \\
\end{tabular} & ICU & Min. $750 \mathrm{ml}$ diuresis & Min. $1200 \mathrm{ml}$ diuresis & $\begin{array}{l}\text { Min. } 1500 \mathrm{ml} \\
\text { diuresis }\end{array}$ & Remove & $\%$ & $\%$ & $\%$ & $\%$ & $\%$ \\
\hline \multicolumn{11}{|l|}{ Medicine } \\
\hline Pain & EPI & EPI + Pinex & EPI + Pinex & $\begin{array}{c}\text { Reduce EPI p.m. + } \\
\text { Pinex + Matrifen }\end{array}$ & $\begin{array}{c}\text { Remove EPI, } \\
\text { continue Pinex + } \\
\text { Matrifen }\end{array}$ & Pinex + Matrifen & Pinex + Matrifen & Pinex + Matrifen & Pinex + Matrifen & Pinex $+1 / 2$ Matrifen \\
\hline $\begin{array}{l}\text { Other } \\
\text { medications }\end{array}$ & ICU & $\begin{array}{c}\text { Pantoprazole }+A B+ \\
\text { Fragmin }\end{array}$ & $\begin{array}{c}\text { Pantoprazole + AB + } \\
\text { Fragmin }\end{array}$ & $\begin{array}{c}\text { Pantoprazole }+A B+ \\
\text { Fragmin }\end{array}$ & $\begin{array}{c}\text { Pantoprazole } \\
\text { (peroral) + Fragmin }\end{array}$ & \begin{tabular}{|c}
$\begin{array}{c}\text { Pantoprazole } \\
\text { (peroral) + Fragmin }\end{array}$ \\
\end{tabular} & $\begin{array}{c}\begin{array}{c}\text { Pantoprazole } \\
\text { (peroral) + Fragmin }\end{array} \\
\end{array}$ & $\begin{array}{c}\text { Pantoprazole } \\
\text { (peroral) + Fragmin }\end{array}$ & $\begin{array}{c}\text { Peroral } \\
\text { Pantoprazole + } \\
\text { Fragmin } \\
\end{array}$ & $\begin{array}{c}\text { Peroral } \\
\text { Pantoprazole + } \\
\text { Fragmin } \\
\end{array}$ \\
\hline \multicolumn{11}{|l|}{ Other } \\
\hline IV fluid & ICU & \begin{tabular}{|c|}
$\begin{array}{c}\text { Daily assessment of } \\
\text { blood sample }+ \\
\text { excretion }\end{array}$ \\
\end{tabular} & $\begin{array}{c}\text { Daily assessment of } \\
\text { blood sample + } \\
\text { excretion }\end{array}$ & \begin{tabular}{|c|}
$\begin{array}{c}\text { Daily assessment of } \\
\text { blood sample + } \\
\text { excretion }\end{array}$ \\
\end{tabular} & \begin{tabular}{|c|}
$\begin{array}{c}\text { Daily assessment of } \\
\text { blood sample + } \\
\text { excretion }\end{array}$ \\
\end{tabular} & \begin{tabular}{|c|}
$\begin{array}{c}\text { Daily assessment of } \\
\text { blood sample + } \\
\text { excretion }\end{array}$ \\
\end{tabular} & \begin{tabular}{|c|}
$\begin{array}{c}\text { Daily assessment of } \\
\text { blood sample + } \\
\text { excretion }\end{array}$ \\
\end{tabular} & \begin{tabular}{|c|}
$\begin{array}{c}\text { Daily assessment of } \\
\text { blood sample + } \\
\text { excretion }\end{array}$ \\
\end{tabular} & \begin{tabular}{|c|}
$\begin{array}{c}\text { Daily assessment } \\
\text { of blood sample + } \\
\text { excretion }\end{array}$ \\
\end{tabular} & $\%$ \\
\hline $\begin{array}{l}\text { Mobilization / } \\
\text { physio- } \\
\text { therapist }\end{array}$ & 4 hours & 6 hours + PT & 8 hours + PT & 8 hours + PT & 8 hours + PT & 8 hours + PT & $\mathrm{x}$ & $\mathrm{x}$ & $\mathrm{x}$ & $\mathrm{x}$ \\
\hline Clinical / Triage & ICU & Triage $\times 3$ daily & Triage $\times 3$ daily & Triage $\times 3$ daily & Triage $\times 3$ daily & Triage $\times 3$ daily & Triage $\times 3$ & Poss. triage $\times 1$ & Triage $\times 1$ & $\%$ \\
\hline Blood tests & $x$ & $x$ & $x$ & $x$ & \%-poss. remove CVC & x-poss. remove CVC & \%-poss. remove $\mathrm{CVC}$ & - poss. remove CVC & $\%$ & $\%$ \\
\hline $\begin{array}{l}\text { Criteria for } \\
\text { discharge }\end{array}$ & \multicolumn{10}{|c|}{ Mobilized, regular bowel movement (acceptable on enema), adequate pain treatment, tubes and catheters removed, future appointments. } \\
\hline Discharge & & & & outpe & & $\begin{array}{l}\text { al of J-tube, } \mathrm{m} \\
\text { on chart. }\end{array}$ & & & & \\
\hline
\end{tabular}

Figure 1. Standardized postoperative recovery program (translated from Danish) following esophagectomy.

\section{Statistical analysis}

Comparison of continuous variable was made by twosample Wilcoxon rank-sum test and comparison of categorical variables by chi-squared test. Statistical analysis was performed using Stata/IC 16.0 for Windows. A p-value of less than 0.05 was considered statistically significant.

\section{Results}

In total, 144 patients were scheduled for curative intended therapy for esophageal or GEJ cancer in 2016 and 2018. Only patients with an uncomplicated postoperative stay after MIO (i.e. patients with a complication degree of less than 3 according to Clavien-Dindo) were analyzed further. Thus, in total 54 patients were excluded (metastatic disease $(n=4)$, non-malignant disease $(n=3)$, planned open procedure or conversion to open $(n=29)$, postoperative complications of 
degree 3 or more $(n=18)$ ). The material then consisted of 48 patients operated from 1 January to 31 December 2016 and 42 patients operated from 1 January to 31 December 2018.

Baseline characteristics for included patients in the two groups are shown in Table 1. There was no significant difference in baseline characteristics between the patients in the two years except for the course of neoadjuvant treatment.
Thus, fewer patients received neoadjuvant treatment in 2018 compared to 2016 (three cases with high grade dysplasia, where neoadjuvant treatment is not recommended, had surgery in 2018. If these cases were excluded there was no difference in the proportions of patients with neoadjuvant treatment).

Table 1. Comparison of baseline characteristics of patients with an uncomplicated course after minimally invasive esophagectomy. Patients followed two different postoperative regimens depending on the year of surgery.

\begin{tabular}{|c|c|c|c|c|c|}
\hline \multirow{2}{*}{ Variables } & \multicolumn{2}{|c|}{$2016(n=48)$} & \multicolumn{2}{|c|}{$2018(n=42)$} & \multirow{2}{*}{ p-value } \\
\hline & $\mathbf{n}$ & $\%$ & $\mathbf{n}$ & $\%$ & \\
\hline Gender & & & & & 0.38 \\
\hline Male & 43 & 89.6 & 35 & 83.3 & \\
\hline Female & 5 & 10.4 & 7 & 16.7 & \\
\hline Age, years, mean \pm SD & $64.6 \pm 8.7$ & & $67.5 \pm 8.3$ & & 0.12 \\
\hline $\mathrm{BMI}, \mathrm{kg} / \mathrm{m} 2$, mean $\pm \mathrm{SD}$ & $25.7 \pm 3.9$ & & $25 \pm 5$ & & 0.39 \\
\hline Preoperative histology & & & & & 0.16 \\
\hline Adenocarcinoma & 44 & 91.7 & 35 & 83.3 & \\
\hline Squamous cell carcinoma & 4 & 8.3 & 4 & 9.5 & \\
\hline High grade dysplasia & 0 & 0 & 3 & 7.1 & \\
\hline ASA classification & & & & & 0.55 \\
\hline I & 1 & 2.1 & 0 & 0 & \\
\hline II & 37 & 77.1 & 35 & 83.3 & \\
\hline III & 10 & 20.8 & 7 & 16.7 & \\
\hline IV-V & 0 & 0 & 0 & 0 & \\
\hline cT stage & & & & & 0.09 \\
\hline $\mathrm{T} 1$ & 1 & 2.1 & 2 & 4.8 & \\
\hline $\mathrm{T} 2$ & 10 & 20.8 & 7 & 16.7 & \\
\hline T3 & 36 & 75 & 26 & 61.9 & \\
\hline $\mathrm{T} 4 \mathrm{a}$ & 1 & 2.1 & 7 & 16.7 & \\
\hline $\mathrm{cN}$ stage & & & & & 0.86 \\
\hline No & 12 & 25 & 10 & 23.8 & \\
\hline N1 & 17 & 35.4 & 15 & 35.7 & \\
\hline N2 & 12 & 25 & 13 & 31 & \\
\hline N3 & 7 & 14.6 & 4 & 9.5 & \\
\hline Neoadjuvant treatment & & & & & 0.04 \\
\hline None & 1 & 2.1 & 7 & 16.7 & \\
\hline Chemotherapy & 44 & 91.7 & 32 & 76.2 & \\
\hline Chemoradiotherapy & 3 & 6.3 & 3 & 7.1 & \\
\hline
\end{tabular}

BMI: Body mass index, ASA: American Society of Anesthesiologists

A comparison of the included patients' complications of Clavien-Dindo degree 0-2 is listed in Table 2. No significant difference in the degree of severity was shown between the two groups. The postoperative complications were mainly due to pneumonia, the need for vasopressor drugs due to hypotension, anastomotic leakage managed conservatively and the need for anti-arrhythmics due to atrial fibrillation. As previously mentioned, 18 patients with Clavien-Dindo complications degree 3 or more (for example anastomotic leakage requiring surgical or endoscopic intervention) were excluded from further analysis. The number of these patients was nine both in 2016 and in 2018.

Table 2. Comparison of surgical complications before (2016) and after standardized (2018) postoperative recovery program following minimally esophagectomy. Patients with complications Clavien-Dindo degree 3 or more were not part of the study.

\begin{tabular}{|c|c|c|c|c|c|}
\hline \multirow{2}{*}{ Clavien-Dindo classification } & \multicolumn{2}{|c|}{$2016(n=48)$} & \multicolumn{2}{|c|}{$2018(n=42)$} & \multirow{2}{*}{ p-value } \\
\hline & $\mathbf{n}$ & $\%$ & $\mathbf{n}$ & $\%$ & \\
\hline 0 (No complications) & 30 & 62.5 & 30 & 71.4 & 0.48 \\
\hline 1 (Any deviation from the normal postoperative course) & 1 & 2.1 & 0 & 0 & \\
\hline 2 (Complication requiring pharmacological treatment) & 17 & 35.4 & 12 & 28.6 & \\
\hline
\end{tabular}

A comparison of LOS between patients in 2016 and 2018 is illustrated in Figure 2. A significant difference $(\mathrm{p}<0.001)$ in the median LOS from 9 days in 2016 to 8 days in 2018 was observed. In total, 27 patients $(64.3 \%)$ fulfilled the aim of discharge to their own home on day 8 after surgery in the 2018-program. In 2016, no specific day was scheduled for discharge, but it was typically expected to be possible on day 9. It was observed that 18 patients (37.5\%) in 2016 and 15 patients $(35.7 \%)$ in 2018 were discharged later than the "standard day" (not significant). Two patients in 2016 (4.2\%) and two patients in $2018(4.8 \%)$ were readmitted within 7 days. The cause of readmission was primary due to poor 
nutritional state and pneumonia. After 30 days, 6 patients had been readmitted in $2016(12.5 \%)$ and 7 patients in 2018 $(16.7 \%)$ (not significant). There was no in-hospital mortality or 30-day mortality in either of the two groups.

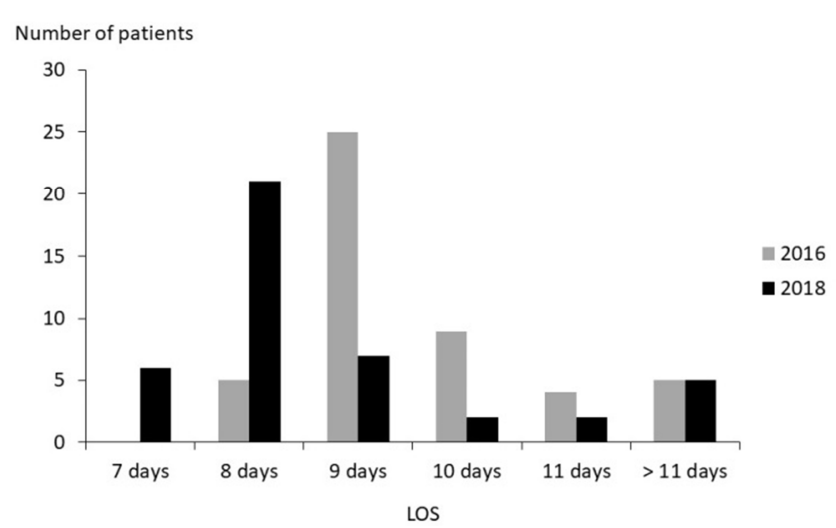

Figure 2. Length of stay (LOS) for patients before (2016) and after standardized (2018) postoperative recovery program following minimally invasive esophagectomy.

\section{Discussion}

This study showed that there was a significant reduction in the LOS by one day when utilizing a standardized postoperative recovery program based on the principles of ERP. Meta-analysis on ERP after esophagectomy have also shown a reduction in $\operatorname{LOS}[11,12]$, but there have also been studies showing no significant effect on LOS in patients following an ERP $[13,14]$. However, all studies have been on comparing the different regimens after esophagectomy by open surgery. The exact reduction in LOS found in our study (one day), where all patients had MIO, is therefore difficult to compare with the reduction in LOS found in the studies from the open era. Thus, several of the studies actual turned out to have a LOS in their ERP group which was longer than the one we had in patients from the period before we introduced our standardized program $[11,12]$.

It can be argued that factors other than the introduction of an ERP could have influence on the postoperative hospitalization. However, at our department no major changes were made between 2016 and 2018. Thus, the perioperative oncological treatment and surgical procedure was unchanged, the same team of surgeons took care of the patients, rounds were made by specialists 7-days a week and discharge were possible every day. We therefore think that the observed reduction in LOS can be attributed to the introduction of the standardized program. However, in order to have success with an ERP it is very important to have a detailed plan for each day and this needs to be known and followed both by the staff and the patient.

One limitation of our study is that it only deals with patients with a relatively uncomplicated postoperative stay (i.e. Clavien-Dindo complications of degree 0-2). In patients with severe complications like anastomotic leakage it was not possible to carry on with the standardized program originally initiated. Thus, these patients were excluded for further analysis because we thought the potential benefit of applying an ERP might be blurred by some patients with a very extended hospitalization due to severe complications. However, it should be noted that the percentage of patients with a severe complicated postoperative stay (i.e. Clavien-Dindo complications of degree 3 to 5) was the same in 2016 and in 2018. In addition, the percentage of patients being rehospitalized in our study did not changed following the introduction of the ERP. This is also an important fact because one might measure the number of patients who fulfill the postoperative recovery program by being discharged at the scheduled day but if a lot of patients are readmitted, this measure is actual of minor clinical relevance. The observed unchanged risk of severe complications or readmittance after the introduction of the ERP in our patients is consistent with the findings in a meta-analysis by Markar et al. [12].

It might be speculated whether it is possible to reduce the postoperative hospitalization further. In our opinion, the main parameter among all the elements of an ERP that keeps the patient hospitalized following an uncomplicated course is getting sufficient nutrition. Previously, surgeons have been very reluctant to allow patients peroral food immediately after esophageal resection. However, a recent published study has shown that oral feeding can be initiated just after surgery without increasing the risk of complications [15], and we will take this information into account in the next revision of our postoperative recovery program.

\section{Conclusion}

The introduction of an ERP at our institution reduced the median postoperative stay after MIO by one day without increasing the risk of complications and readmittance. Further reduction might be obtained if oral feeding is allowed earlier.

\section{References}

[1] Van der Sluis PC, Schizas D, Liakakos T et al. Minimally invasive esophagectomy. Dig Surg 2020; 37: 93-100.

[2] Ainsworth AP, Larsen MH, Ladegaard L et al. Short-term outcomes after minimally invasive oesophagectomy. Dan Med J 2019; 66: A5559.

[3] Elias KM. Understanding enhanced recovery after surgery guidelines: An introductory approach. J Laparoendosc Adv Surg Tech A 2017; 27: 871-5.

[4] Ljungqvist O, Scott M, Fearon KC. Enhanced recovery after surgery: A review. JAMA Surg 2017; 152: 292-8.

[5] Kehlet H. Multimodal approach to control postoperative pathophysiology and rehabilitation. Br J Anaesth. 1997; 78: 606-17.

[6] Lassen K, Soop M, Nygren J et al. Consensus review of optimal perioperative care in colorectal surgery: Enhanced Recovery After Surgery (ERAS) Group recommendations. Arch Surg 2009; 144: 961-9. 
[7] Melloul E, Hubner $M$, Scott $M$ et al. Guidelines for perioperative care for liver surgery: Enhanced Recovery After Surgery (ERAS) Society recommendations. World J Surg 2016; 40: 2425-40.

[8] Mortensen K, Nilsson M, Slim K et al. Consensus guidelines for enhanced recovery after gastrectomy: Enhanced Recovery After Surgery (ERAS $\left.{ }^{\circledR}\right)$ Society recommendations. Br J Surg 2014; 101: 1209-29.

[9] Low DE, Allum W, Manzoni GD et al. Guidelines for Perioperative Care in Esophagectomy: Enhanced Recovery After Surgery (ERAS $\left.{ }^{\circledR}\right)$ Society Recommendations. World J Surg 2019; 43: 299-330.

[10] Dindo D, Demartines N, Clavien PA. Classification of surgical complications: a new proposal with evaluation in a cohort of 6336 patients and results of a survey. Ann Surg 2004; 240: 205-13.

[11] Gemmill EH, Humes DJ, Catton JA. Systematic review of enhanced recovery after gastro-oesophageal cancer surgery. Ann R Coll Surg Engl 2015; 97: 173-9.
[12] Markar SR, Karthikesalingam A, Low DE. Enhanced recovery pathways lead to an improvement in postoperative outcomes following esophagectomy: systematic review and pooled analysis. Dis Esophagus 2015; 28: 468-75.

[13] Findlay JM, Tustian E, Millo J et a. The effect of formalizing enhanced recovery after esophagectomy with a protocol. Dis Esophagus 2015; 28: 567-73.

[14] Giacopuzzi S, Weindelmayer J, Treppiedi E et al. Enhanced recovery after surgery protocol in patients undergoing esophagectomy for cancer: a single center experience. Dis Esophagus 2017; 30: 1-6.

[15] Berkelmans GHK, Fransen LFC, Dolmans-Zwartjes ACP et al. Direct oral feeding following minimally invasive esophagectomy (NUTRIENT II trial): An international, multicenter, open-label randomized controlled trial. Ann Surg 2020; 271: 41-7. 